\title{
Understanding the patterns of fish and seafood consumption and their nutritional roles among a selected population in Malaysia to inform sustainable development
}

\author{
Ee Von Goh ${ }^{\mathrm{a} *}$, Susan Azam Ali ${ }^{\mathrm{a}}$, Soma Roy Mitra ${ }^{\mathrm{a}}$, Fiona McCullough ${ }^{\mathrm{b}}$ \\ ${ }^{a}$ School of Biosciences, Faculty of Science and Engineering, University of Nottingham Malaysia, Malaysia. \\ ${ }^{b}$ School of Biosciences, Faculty of Science, University of Nottingham, United Kingdom. \\ *Corresponding author's E-mail address: eevon.goh@nottingham.edu.my
}

\begin{abstract}
This study was designed to generate baseline data of the fish and seafood consumption pattern among major ethnics in urban, rural, and coastal regions of Peninsular Malaysia. A food frequency questionnaire was adapted and administered on healthy adult participants above 18 years. Fish and seafood is the prime animal protein source in Malaysian diet, comprising about onethird of total animal protein consumed. Average per capita fish and seafood consumption is $44.53 \mathrm{~kg} / \mathrm{year}$, with higher levels observed in coastal $(51.9 \mathrm{~kg} / \mathrm{year})$ and rural $(51.8 \mathrm{~kg} / \mathrm{year})$ than urban areas $(36.9 \mathrm{~kg} / \mathrm{year})$. While the fish and seafood intake is relatively high, the total polyunsaturated fatty acids intake is borderline low. Despite cross- cultural and regional variations, there is a great overall preference for wild caught marine pelagic fishes. The demand has to be satisfied by imports, even after increasing local fishing effort. The data are beneficial for sustainability assessment and to inform policies for a sustainable food future.
\end{abstract}

Keywords - Sustainable diet, Environmental sustainability, Food systems, Food policy, Fish consumption

\section{INTRODUCTION}

Malaysia has one of the highest per capita fish and seafood (F\&S) supplies in the world, more than double the global average of $20.5 \mathrm{~kg}$ (FAO, 2020). According to FAO Food Balance Sheets, the annual per capita F\&S supplies have been consistently around 56kg/year since 1995, a 40\% increase since 1980 . However, this estimation of per capita supply does not represent the amount of food that is actually consumed. Rather, it reflects "the long term trend of national per capita supply for human consumption and represents the food produced and imported into countries minus the food exported net of imports, fed to animals, or otherwise not available for human consumption, divided by population size" (FAO, 2001). In the absence of food intake data, the information from food balance sheets can be used as a proxy indicator of food security, however, it is likely that this derivation of per capita supply overestimates food consumption when compared to individual dietary surveys (Kearney, 2010).

Assuming that the per capita F\&S supply is closely related to its actual consumption, there are potential ecological and health consequences for Malaysia. The everincreasing demand for $F \& S$ due to increased population size will place high demands on the wild stock, especially if it is harvested at a rate that outstrips natural reproduction. In addition to overfishing, there are a number of external factors that threaten the long-term sustainability of the ocean's resources, including ocean warming and acidification, aquatic hypoxia and pollution, all of which negatively impact on fish stocks (FAO, 2005). Aquaculture or farmed F\&S offers the potential to alleviate pressure on the reserves of wild-caught sea and freshwater F\&S. However, this option is not without potential environmental and health impacts, especially in terms of pollution, and through the introduction of undesirable chemical substances.

The adoption of healthy and sustainable diets and food systems is increasingly recognised as a key strategy in achieving the Sustainable Development Goals (SDGs) (FAO \& WHO, 2019). To gain an overview of the sustainability of the current F\&S consumption habit and how the food system can keep pace with increasing population size and demand, there is a need to understand actual consumer intake levels of F\&S, and the diversity of species consumed. Malaysia is a multi-ethnic country and the F\&S types available in Malaysia are remarkably diverse and each type differs in terms of habitat, fishing and/or farming methods, nutritional value, and environmental impact. Although a few food consumption surveys have been conducted at the national level (Institute of Public Health, 2008a, 2008b \& 2014; Ahmad et al., 2016), there is no detailed study of the magnitude and diversity of the F\&S consumption habit of Malaysians. Comprehensive data on the amount and species consumed by Malaysian is lacking. Hence, this study was designed to assess the habitual 
consumption of F\&S by Malaysians over a 12-month reference period. The specific objectives of the study were:

1. To explore and compare the consumption patterns of farmed and wild caught F\&S between the coastal, rural, and urban Peninsular Malaysians across three major ethnic groups.

2. To identify and report popular F\&S species consumed in the above geographical locations and ethnic groups.

3. To assess and quantify the contribution of $F \& S$ to the total protein and essential fatty acid intake in adult Peninsular Malaysians

This study provides baseline information on the crosscultural and regional differences in F\&S consumption pattern of adults living in Peninsular Malaysia. It is a necessary first step to facilitate future work in exploring the implications of this dietary pattern across the food system from a sustainability perspective, and ultimately towards devising sustainable development strategies in line with the growing interest in sustainable healthy diets (FAO \& WHO, 2019).

\section{MATERIALS AND METHODS}

\section{A. Study Design}

Data for this study was collected in 2015-16. Based on practicality, the survey was conducted in the Kuala Lumpur and Selangor. Often referred to collectively as Klang Valley, it is an area in Peninsular Malaysia that is centred in Kuala Lumpur (with a population density of $6,891 / \mathrm{km}^{2}$ in 2010 census) and includes its adjoining cities and towns in the state of Selangor (Figure 1). Peninsular Malaysia accounts for the majority (roughly $80 \%$ in 2010 census) of Malaysia's population, with Klang Valley being the most populous region. To ensure the survey included a cross-section of the population, it was carried out in three distinctly different locations - urban, rural, and coastal towns, and with participants from all three major ethnic groups. Samples of the coastal population were collected from Kuala Selangor, a coastal town with a population density of $170 / \mathrm{km}^{2}(2010$ census) about $60 \mathrm{~km}$ from central Kuala Lumpur (Figure 1). The rural population were recruited in Hulu Selangor, a rural district about $50 \mathrm{~km}$ from central Kuala Lumpur (Figure 1) and with a population density of $110 / \mathrm{km}^{2}$ (2010 census).

Participants were recruited via street-intercept. Potential participants were approached for screening and were informed about the study. Participants were selected based on a purposive sampling technique. The inclusion criteria of the participants were being (1) local citizen; (2) aged at least 18 years; (3) healthy and had no known illnesses; (4) able to give informed consent. Exclusion criteria were adults who have recently changed their dietary consumption habits and those practising vegetarianism. Verbal consent was sought before being interviewed using a semi-quantitative food frequency questionnaire (FFQ). Demographic and anthropometric data such as weight and height were selfreported.
A total of 402 adults participated and completed the FFQ interview. Assuming a $95 \%$ confidence level with a margin error of $5 \%$, a minimum of 385 samples were required. In fact, Gay (1996) has suggested that if the population size is beyond a certain point (at approximately $\mathrm{N}=5,000$ ), the population size is almost irrelevant, and a sample size of 400 will be adequate (Gay, 1996).

\section{B. Development and Validation of the FFQ}

An existing validated FFQ developed by the University of Science Malaysia (USMFFQ) was adopted for this study. The design and methods of USMFFQ are described in more detail elsewhere (Loy et al., 2011). The original USMFFQ was designed for use in the Malay ethnic group, therefore, it was adjusted to reflect the general makeup of the Malaysian population (Malay, Chinese and Indian) for use in this study. This entailed the development of a cross-culturally robust food list and the section on F\&S was expanded to provide more detail on the types of F\&S consumed.

To adapt the USMFFQ, a single 24-hour dietary recall survey (24hDR) was carried out among 80 adults, aged 18 60 years, in the urban Klang Valley $(n=40)$, rural Hulu Selangor $(n=20)$ and coastal Kuala Selangor $(n=20)$. Pooled data were used in this study, thereby alleviating the need for multiple interviews to minimise within-person variation. A total of 208 food items were pooled from these $24 \mathrm{hDR}$ participants. The food items were cross-checked against those listed in USMFFQ and those not listed were selected based on a $15 \%$ frequency cut-off (Ferreira et al., 2010). To reduce research burden, the resulted food list was further reduced to a nested list (except for $F \& S$ ) by aggregating conceptually similar foods based on their nutrient content per portion eaten. The food list in FFQ (excluding F\&S) had 148 items categorised under 11 main food groups, which were: (1) Cereals and cereal products; (2) Meat and meat products; (3) Eggs; (4) Legumes and pulses; (5) Milk and dairy products; (6) Vegetables; (7) Fruits; (8) Beverages; (9) Confections; (10) Bread spread; (11) Condiments.

For F\&S, a visual handout containing a comprehensive list of $F \& S$ species with matching photographs was created for FFQ administration. FFQ participants were asked to identify the types of F\&S that they consumed based on the visual handout. The comprehensive list of F\&S species commonly available and consumed was generated based on the $24 \mathrm{hDR}$ and F\&S availability surveys conducted during adaptation phase. Participants of $24 \mathrm{hDR}$ who reported to have consumed $F \& S$ were asked to name it, with support of F\&S photographs. To complement and verify the $24 \mathrm{hDR}$, a F\&S availability survey was conducted at various grocers, markets and restaurants in the Klang Valley and Selangor. To categorise the F\&S as wild or farmed, assumptions were made based on comparison of data of capture fishery landing and seedling hatchery. Aquaculture consultants, F\&S suppliers and fishmongers were consulted to confirm if the wild and farmed F\&S were appropriately categorised.

Summary questions on overall intake of each of the twelve food groups in the FFQ were added for cross checking purpose. The frequency of intake was based on 
habitual intake over the past twelve months; there were four options, which were 'per day', 'per week', 'per month' and 'never'. Participants were asked to estimate the number of portion size consumed relative to the portion size measurement photograph in the Malaysian Atlas of Food Exchanges and Portion Sizes (Suzana et al., 2009). Several approaches were used to validate the adapted FFQ in this study: content validity, face validity and external validity. The FFQ was reviewed by three local nutritionists to confirm content validity. Comprehensibility of the newly developed FFQ was evaluated on 20 participants and appropriate adjustments were subsequently made. To confirm external validity, the characteristics of current survey population were compared to national population estimate (DoSM, 2016).

\section{Handling of Mis-reporting of Energy and Nutrient Intake}

The reported energy intake (EI) was validated using the Goldberg cut-off method (Goldberg et al., 1991) because it has a high predictive value even in the absence of objective measures of total energy expenditure (TEE) or physical activity Tooze et al., 2012). The EI and basal metabolic rate (BMR) of participants were first expressed as an index (EI/BMR), and then compared with the presumed mean EE. Estimates of BMR were calculated from an equation established for use in Malaysian adults (Ismail et al., 1998). Cut-off points for EI/BMR ratio for under- and overreporting were 1.2 and 1.8, respectively (Bingham, 1994). The magnitude of mis-reporting was expressed as the prevalence and extent of under- or overestimation of intake (Poslusna et al., 2009). Because the exclusion of misreporters introduces a source of unknown bias (Gibson, 2005), the mis-reporters were included in the dataset as necessary. To adjust for energy intake, the nutrient-density model, where dietary variables are expressed as their intake per $1000 \mathrm{kcal}$ (Poslusna et al., 2009), is employed as it does not require any statistical models and is used in national dietary guidelines (Drewnowski, 2005).

\section{Statistical Analyses}

Nutrient intakes were calculated using an in-house FFQ calculator, a customised Microsoft Excel spreadsheet. This FFQ calculator is based on the participant's frequency of consumption, amount of the item consumed and amount of nutrient in the serving size indicated. Nutrient values for each food item were derived from the Malaysian Food Composition Tables (Tee et al., 1997). For food items not available in the Malaysian Food Composition Tables, other food databases such as the Singapore Food Composition Database (Ministry of Health Singapore, 2011) and ASEAN Food Composition Tables (Puwastien et al., 2000) were referred to. For processed foods, composition data were obtained from nutritional labels.

Statistical Package for Social Sciences (SPSS) version 22.0 was used for statistical analysis. Intake distributions were presented as mean \pm SD and/or median, 25th and 75th percentiles to characterise population intake levels for gender, and socio-demographic characteristics. Data associations were calculated with the Kruskal-Wallis test,
Mann-Whitney U-test, independent T-test, independent median test or ANOVA, depending on normality of data, followed by Tukey or Dunnett's T3 post hoc test when necessary. Statistical significance was considered at $\mathrm{p} \leq$ 0.05 .

\section{RESULTS}

\section{Subject Characteristics}

The demographic characteristics of the participants recruited into the survey (Table 1) were broadly in line with the National Census, albeit with a slightly lower proportions of male and Malays (DoSM, 2016). The representative sample had a similar age distribution to the National Census, with the average age of participant being 37.1 \pm 14.9 years old. Mean BMI was $24.6 \pm 4.7 \mathrm{~kg} / \mathrm{m}^{2}$. The BMI characteristics and trends were generally in accordance with those reported in national dietary surveys (Institute of Public Health, 2008a, 2008b \& 2014; Ahmad et al., 2016).

Table 1: Socio-demographic characteristics of participants of current study vs Department of Statistics Malaysia (DoSM, 2016)

\begin{tabular}{llll}
\hline Characteristics & \multicolumn{2}{c}{$\begin{array}{l}\text { Current Study } \\
(\mathbf{N}=\mathbf{3 9 1})\end{array}$} & DoSM (2016) ${ }^{(\mathbf{1 4})}$ \\
\cline { 2 - 4 } & $\mathrm{n}$ & $(\%)$ & $(\%)$ \\
\hline Gender & & & \\
Male & 176 & 45.0 & 51.3 \\
Female & 215 & 55.0 & 48.7 \\
\hline Ethnicity & & & \\
Malay & 182 & 46.5 & 57 \\
Chinese & 141 & 36.1 & 31 \\
Indian & 68 & 17.4 & 12 \\
\hline Geographical Location & & & \\
Urban & 191 & 48.8 & - \\
Coastal & 100 & 25.6 & - \\
Rural & 100 & 25.6 & - \\
Age Group (years) & & & - \\
$\mathbf{1 8}-\mathbf{1 9}$ & 28 & 7.2 & 30.0 \\
$\mathbf{2 0 - 2 9}$ & 131 & 33.5 & 28.5 \\
$\mathbf{3 0 - 3 9}$ & 78 & 20.0 & 18.3 \\
$\mathbf{4 0 - 4 9}$ & 67 & 17.1 & 12.5 \\
$\mathbf{5 0}-\mathbf{5 9}$ & 51 & 13.0 & 10.7 \\
$>\mathbf{6 0}$ & 36 & 9.2 & \\
& & & \\
\hline
\end{tabular}

\section{Energy Intake and Prevalence of Mis-reporting}

The mean energy intake of all participants $(n=391)$ was $1609.6 \mathrm{kcal} / \mathrm{capita} /$ day and increased to $1903.6 \pm 557.9$ $\mathrm{kcal} / \mathrm{capita} /$ day after exclusion of mis-reporters $(\mathrm{n}=147)$. Under-reporters and over-reporters comprised of $35.8 \%$ $(n=140)$ and $1.8 \% \quad(n=7)$ of the sample population, respectively. Based on the mean BMI, an average female and male adult from the sample population would require $1860 \mathrm{kcal}$ and $2232 \mathrm{kcal}$ respectively, without net energy balance. Assuming all participants were maintaining their weight, the actual mean energy intake of female and male participants was underestimated by only $9.4 \%$ and $4.3 \%$ respectively, after accounting for mis-reporters.

\section{Intake of Protein}

The mean total protein intake was $36.4 \pm 8.2 \mathrm{~g} / 1000 \mathrm{kcal}$, of which $20.8 \pm 11.9 \mathrm{~g} / 1000 \mathrm{kcal}$ was animal-sourced protein. The plant to animal protein ratio was $3: 4$. While total protein intake was similar among all groups, animal protein intake was significantly influenced by geographical location, gender and ethnicity (Table 2): urban and male participants 
consumed more animal protein than their counterparts; Chinese consumed significantly more animal protein than the Malay while the Indians consumed the least.

Table 2: The distribution (mean $\pm \mathrm{SD}$ ) of total protein and animal protein intake $(\mathrm{g} / 1000 \mathrm{kcal})$ of all participants

\begin{tabular}{|c|c|c|c|c|}
\hline \multirow[t]{2}{*}{ Characteristics $(\mathrm{N}=391)$} & \multicolumn{2}{|c|}{$\begin{array}{l}\text { Total Protein } \\
\text { (g/1000kcal) }\end{array}$} & \multicolumn{2}{|c|}{$\begin{array}{l}\text { Animal Protein } \\
\text { (g/1000kcal) }\end{array}$} \\
\hline & Mean & $\pm \mathrm{SD}$ & Mean & $\pm \mathrm{SD}$ \\
\hline \multicolumn{5}{|l|}{ Gender } \\
\hline Male (n=176) & 35.7 & 8.0 & $22.2^{*}$ & 13.2 \\
\hline Female (n=215) & 37.0 & 8.3 & $19.7^{*}$ & 10.6 \\
\hline \multicolumn{5}{|l|}{ Ethnicity } \\
\hline Malay (n=182) & 37.0 & 7.8 & $20.0^{*}$ & 11.4 \\
\hline Chinese $(n=141)$ & 36.6 & 8.6 & $24.1^{*}$ & 12.8 \\
\hline Indian (n=68) & 34.7 & 8.2 & $16.4^{*}$ & 9.2 \\
\hline \multicolumn{5}{|l|}{ Geographical Location } \\
\hline Urban (n=191) & 37.1 & 8.4 & $22.8^{*}$ & 12.9 \\
\hline Coastal (n=100) & 36.3 & 8.2 & 17.5 & 8.8 \\
\hline Rural (n=100) & 35.3 & 7.6 & 20.4 & 11.9 \\
\hline
\end{tabular}

\section{Types of Animal Protein Consumed}

Overall, F\&S was the largest contributor to animal protein $(34.6 \%)$, followed by chicken $(26.8 \%)$ and eggs (17.9\%) (Table 3). Lamb $(2.0 \%)$ and duck $(0.7 \%)$ were unpopular choices (Table 3). Geographical location, gender and ethnicity influence the type of animal protein consumed. Males consumed significantly less F\&S and more beef and lamb than females $(\mathrm{p}<0.05)$. Malays consumed significantly more beef $(\mathrm{p}<0.01)$ than Chinese and Indians. Because a significant number of Chinese and Indian participants follow Buddhism and Hinduism, the proportion of beef intake among these two ethnic groups was very low. On average, the Chinese consumed significantly less F\&S $(\mathrm{p}<0.01)$ but more pork $(\mathrm{p}<0.01)$ than both Malay and Indian ethnic groups. Considering religious sensitivity, pork was excluded from the list of food items during interviews with Malay participants and thus, zero consumption of pork was assumed for this category. By geographical location, the urban participants consumed the least proportion of $F \& S$ $(p<0.05)$. Since a higher proportion of ethnic Chinese reside in urban areas, the consumption of pork was significantly higher there $(\mathrm{p}<0.5)$.

Table 3: The percentage contribution of different sources of animal protein to the total protein intake

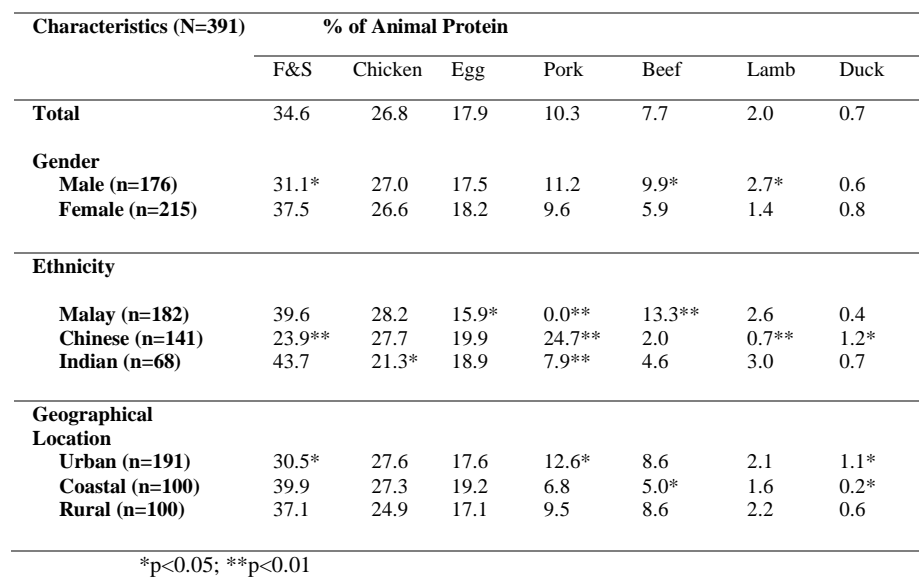

\section{F\&S Consumption Pattern}

To obtain a more accurate reflection of the magnitude of F\&S consumption, under-reporters were excluded from the calculation of total F\&S intake. The estimated daily consumption of raw weight of F\&S was $122 \mathrm{~g} /$ day, which equates to around $44.5 \mathrm{~kg} / \mathrm{capita} / \mathrm{year}$. On average, per capita F\&S consumption was substantially higher in coastal $(51.9 \mathrm{~kg} / \mathrm{capita} / \mathrm{year})$ and rural areas $(51.8 \mathrm{~kg} / \mathrm{capita} / \mathrm{year})$ than in urban areas $(36.9 \mathrm{~kg} /$ capita/year).

The top $15 \mathrm{~F} \& S$ species were ranked according to total annual consumption. The most consumed $F \& S$, on a weight basis (Table $4 \& 5$ ), were from the scombrids (Indian mackerel, Spanish mackerel, sardines, small tuna) or carangids (pomfrets and scads). These small fish are exclusively wild captured. Red tilapia, which is the third most popular consumed F\&S overall, and commonly consumed in both rural and urban areas, is a farmed species. This fish was the least popular species of coastal participants. Comparison of the most popular F\&S according to geographical location indicates that mackerel is the most consumed F\&S across all groups (Table 5). Anchovies, which are the most popular F\&S by prevalence of consumption, but due to the small size do not feature in the top 15 species on a weight basis, are exclusively wild captured. After anchovies and Indian mackerel, the third most prevalent species is Vannamei prawns. These prawns, which are predominantly farmed in fresh water, are consumed fairly frequently, but in small amounts, such that they ranked $11^{\text {th }}$ on a weight basis by participants in all regions.

Table 4: Ranking of the top 15 F\&S by prevalence of consumption $(\%)$ and weight $(\mathrm{kg})$ of total sample population

\begin{tabular}{llllll}
\hline Rank & English Name & $\begin{array}{l}\text { Prevalence } \\
\text { of } \\
\text { consumptio } \\
\mathbf{n}(\mathbf{\%})\end{array}$ & Rank & English Name & $\begin{array}{l}\text { Annual } \\
\text { capita } \\
\text { for } \begin{array}{c}\text { per } \\
\text { weight } \\
\text { population } \\
\text { (kg) }\end{array}\end{array}$ \\
\hline $\mathbf{1}$ & Anchovies & 54.2 & 1 & Indian Mackerel & 7.11 \\
\hline $\mathbf{2}$ & Indian Mackerel & 48.1 & 2 & Spanish Mackerel & 3.45 \\
\hline $\mathbf{3}$ & Vannamei Prawn & 32.7 & 3 & Red Tilapia & 2.31 \\
\hline $\mathbf{4}$ & Black Pomfret & 31.2 & 4 & Stingray & 1.89 \\
\hline $\mathbf{5}$ & Spanish Mackerel & 29.4 & 5 & Black Pomfret & 1.53 \\
\hline $\mathbf{6}$ & Red Tilapia & 26.9 & 6 & Small Tuna & 1.27 \\
\hline $\mathbf{7}$ & Blood Cockles & 23.3 & 7 & Vannamei Prawn & 1.26 \\
\hline $\mathbf{8}$ & Sardine & 21.5 & 8 & Round Scad & 1.24 \\
\hline $\mathbf{9}$ & White Pomfret & 21.2 & 9 & Barramundi & 1.16 \\
\hline $\mathbf{1 0}$ & Sea Prawns & 21.0 & 10 & Catfish & 1.16 \\
\hline $\mathbf{1 1}$ & Tiger Prawns & 20.2 & 11 & Threadfin Bream & 1.05 \\
\hline $\mathbf{1 2}$ & Stingrays & 17.9 & 12 & Tiger Prawn & 0.95 \\
\hline $\mathbf{1 3}$ & Barramundi & 15.3 & 13 & Hardtail Scad & 0.95 \\
\hline $\mathbf{1 4}$ & Threadfin Bream & 14.6 & 14 & White Pomfret & 0.95 \\
\hline $\mathbf{1 5}$ & Fish ball & 14.3 & 15 & Sea Prawn & 0.87 \\
\hline & Footnote: Latin names of the F\&S listed can be found in Appendix I. & \\
\hline & & & & \\
\hline
\end{tabular}


Table 5: Ranked annual per capita consumption (kg/year) of the top $15 \mathrm{~F} \& S$ of the total sample population according to geographical locations

\begin{tabular}{|c|c|c|c|c|c|c|}
\hline \multirow[b]{2}{*}{ Rank } & \multicolumn{2}{|l|}{ Urban } & \multicolumn{2}{|l|}{ Rural } & \multicolumn{2}{|c|}{ Coastal } \\
\hline & $\begin{array}{l}\text { English } \\
\text { Name }\end{array}$ & $\begin{array}{l}\text { Per } \\
\text { Capita } \\
\text { (kg/year) }\end{array}$ & $\begin{array}{l}\text { English } \\
\text { Name }\end{array}$ & $\begin{array}{l}\text { Per } \\
\text { Capita } \\
\text { (kg/year) }\end{array}$ & $\begin{array}{l}\text { English } \\
\text { Name }\end{array}$ & $\begin{array}{l}\text { Per } \\
\text { Capita } \\
\text { (kg/year) }\end{array}$ \\
\hline 1 & $\begin{array}{l}\text { Indian } \\
\text { Mackerel }\end{array}$ & 5.43 & $\begin{array}{l}\text { Indian } \\
\text { Mackerel }\end{array}$ & 6.33 & $\begin{array}{l}\text { Indian } \\
\text { Mackerel }\end{array}$ & 11.12 \\
\hline 2 & Sardine & 3.38 & $\begin{array}{l}\text { Spanish } \\
\text { Mackerel }\end{array}$ & 5.12 & $\begin{array}{l}\text { "Keropok } \\
\text { Lekor" }\end{array}$ & 8.23 \\
\hline 3 & $\begin{array}{l}\text { Spanish } \\
\text { Mackerel }\end{array}$ & 3.27 & Red Tilapia ${ }^{\mathrm{pf}}$ & 4.17 & Stingray & 2.98 \\
\hline 4 & Red Tilapia ${ }^{\mathrm{pf}}$ & 2.04 & Sardine & 3.66 & $\begin{array}{l}\text { Threadfin } \\
\text { Bream }\end{array}$ & 2.34 \\
\hline 5 & Barramundip & 1.74 & Round Scad & 2.28 & $\begin{array}{l}\text { Small } \\
\text { Tuna }\end{array}$ & 2.13 \\
\hline 6 & $\begin{array}{l}\text { Black } \\
\text { Pomfret }\end{array}$ & 1.47 & $\begin{array}{l}\text { "Keropok } \\
\text { Lekor" }\end{array}$ & 2.28 & $\begin{array}{l}\text { Spanish } \\
\text { Mackerel }\end{array}$ & 2.13 \\
\hline 7 & Stingray & 1.44 & $\begin{array}{l}\text { Black } \\
\text { Pomfret }\end{array}$ & 2.12 & $\begin{array}{l}\text { White } \\
\text { Pomfret }\end{array}$ & 1.61 \\
\hline 8 & "Lala" Clam & 1.24 & Catfish ${ }^{\mathrm{pf}}$ & 2.09 & Sardine & 1.48 \\
\hline 9 & $\begin{array}{l}\text { "Keropok } \\
\text { Lekor" }\end{array}$ & 1.24 & Barramundi ${ }^{p}$ & 1.86 & $\begin{array}{l}\text { Tiger } \\
\text { Prawn }^{\mathrm{pf}}\end{array}$ & 1.35 \\
\hline 10 & Salmon ${ }^{p}$ & 1.19 & $\begin{array}{l}\text { Big Head } \\
\text { Carpp }^{p f}\end{array}$ & 1.54 & $\begin{array}{l}\text { Sea } \\
\text { Prawn }\end{array}$ & 1.28 \\
\hline 11 & $\begin{array}{l}\text { Vannamei } \\
\text { Prawn }^{\mathrm{pf}}\end{array}$ & 1.12 & $\begin{array}{l}\text { Vannamei } \\
\text { Prawn }^{\mathrm{pf}}\end{array}$ & 1.54 & $\begin{array}{l}\text { Vanname } \\
\text { i Prawn }\end{array}$ & 1.25 \\
\hline 12 & Round Scad & 0.93 & $\begin{array}{l}\text { Hardtail } \\
\text { Scad }\end{array}$ & 1.52 & $\begin{array}{l}\text { Fourfinger } \\
\text { Threadfin }\end{array}$ & 1.23 \\
\hline 13 & Tiger Prawn ${ }^{\mathrm{p}}$ & 0.81 & $\begin{array}{l}\text { Red } \\
\text { Snapper }^{p}\end{array}$ & 1.34 & $\begin{array}{l}\text { Black } \\
\text { Pomfret }\end{array}$ & 1.08 \\
\hline 14 & Small Tuna & 0.80 & Stingray & 1.33 & Sole Fish & 1.03 \\
\hline 15 & $\begin{array}{l}\text { Blood } \\
\text { Cockles }^{\mathrm{p}}\end{array}$ & 0.78 & Small Tuna & 1.31 & $\begin{array}{l}\text { Red } \\
\text { Tilapia }^{\mathrm{pf}}\end{array}$ & 0.97 \\
\hline
\end{tabular}

Footnote: Latin names of the F\&S listed can be found in Appendix I; $p=$ predominantly farmed; $f=$ freshwater

Referring to Table 5, rural participants consumed the most farmed and freshwater F\&S, followed by the urban participants. The coastal dwellers, on the other hand, preferred wild marine F\&S. Only one farmed species, red tilapia, featured at number 15 in the list of preferred species of coastal dwellers. All the commonly consumed F\&S species are endemic to Malaysia, except for salmon. Salmon, a relatively expensive fish as it is solely imported, appeared as the $10^{\text {th }}$ most consumed F\&S (by weight) in the urban region. It is, however, the least common $F \& S$ in the rural and coastal regions and did not appear in the top 15 for these groups. The urban participants also consumed the most bivalves, i.e. "Lala" clams and blood cockles. Keropok lekor, a traditional fish finger commonly made with mackerel flesh, was a popular snack among all participants, especially in the coastal region.

Table 6: The distribution of farmed F\&S (\%) out of the total amount of F\&S consumed

\begin{tabular}{|c|c|c|c|c|c|}
\hline & \multicolumn{5}{|c|}{ Percentage of Farmed F\&S Out of Total F\&S Consumed (\%) } \\
\hline & \multirow[t]{2}{*}{ Mean } & \multirow[t]{2}{*}{$\pm \mathrm{SD}$} & \multirow[t]{2}{*}{ Median } & \multicolumn{2}{|c|}{ Percentiles } \\
\hline & & & & 25 & 75 \\
\hline Total $(\mathrm{N}=391)$ & 24.9 & 26.1 & 16.2 & 3.5 & 42.3 \\
\hline \multicolumn{6}{|l|}{ Gender } \\
\hline Male $(n=176)$ & $28.1^{*}$ & 27.9 & 18.7 & 4.9 & 44.5 \\
\hline Female (n=215) & 22.3 & 24.2 & 14.3 & 1.6 & 40.7 \\
\hline \multicolumn{6}{|l|}{ Ethnicity } \\
\hline Malay (n=182) & 22.2 & 23.2 & 14.4 & 3.3 & 39.5 \\
\hline Chinese $(n=141)$ & $31.0^{*}$ & 28.4 & $20.3 *$ & 5.5 & 51.0 \\
\hline Indian $(n=68)$ & 19.8 & 26.5 & 7.7 & 0.5 & 30.3 \\
\hline \multicolumn{6}{|c|}{ Geographical Location } \\
\hline Urban (n=191) & 26.1 & 27.3 & 15.7 & 1.5 & 46.3 \\
\hline Coastal $(n=100)$ & $20.0^{*}$ & 22.8 & 13.3 & 3.8 & 27.3 \\
\hline Rural $(n=100)$ & 27.7 & 26.3 & 19.6 & 5.3 & 43.7 \\
\hline
\end{tabular}

Overall, a mean and median of approximately $25 \%$ and $16 \%$ of $\mathrm{F} \& \mathrm{~S}$ consumed by the sample population was farmed (Table 6). Around 17\% $(n=68)$ of the sample population acquired $50 \%$ of their total F\&S from farmed sources (which mainly comprised of Vannamei prawn). The males and Chinese consumed significantly more farmed F\&S than their counterparts $(\mathrm{p}<0.05)$ (Table 6). The coastal dwellers consumed a significantly smaller proportion of farmed F\&S than their counterparts $(\mathrm{p}<0.05)$ (Table 6).

\section{Fat Intake}

Table 7: Daily fat intake (g/1000 kCal) (total fat, SFA, MUFA and PUFA) according to gender, ethnicity, and geographical region

\begin{tabular}{|c|c|c|c|c|}
\hline & $\begin{array}{l}\text { Total Fat } \\
\text { (g/1000kcal) }\end{array}$ & $\begin{array}{l}\text { SFA } \\
\text { (g/1000kcal) }\end{array}$ & $\begin{array}{l}\text { MUFA } \\
\text { (g/1000kcal) }\end{array}$ & $\begin{array}{l}\text { PUFA } \\
\text { (g/1000kcal) }\end{array}$ \\
\hline & Mean $( \pm$ SD) & Mean $( \pm$ SD $)$ & Mean $( \pm$ SD $)$ & Mean $( \pm \mathrm{SD})$ \\
\hline Total $(\mathrm{N}=391)$ & $24.9(6.2)$ & $10.7(2.9)$ & $9.3(2.9)$ & $4.3(1.4)$ \\
\hline \multicolumn{5}{|l|}{ Gender } \\
\hline Male $(n=176)$ & $25.1(6.4)$ & $10.7(2.9)$ & $9.3(2.9)$ & $4.3(1.5)$ \\
\hline Female (n=215) & $24.8(6.1)$ & $10.6(2.9)$ & $9.3(2.9)$ & $4.2(1.3)$ \\
\hline \multicolumn{5}{|l|}{ Ethnicity } \\
\hline Malay (n=182) & $25.1(6.0)$ & $11.0(2.7)$ & $9.3(2.7)$ & $4.3(1.3)$ \\
\hline Chinese $(n=141)$ & $24.6(6.6)$ & $10.1(3.1)^{*}$ & $9.4(3.1)$ & $4.3(1.4)$ \\
\hline Indian (n=68) & $25.1(5.9)$ & $11.0(3.0)$ & $9.1(3.1)$ & $4.1(1.4)$ \\
\hline \multicolumn{5}{|l|}{ Geographical } \\
\hline \multicolumn{5}{|l|}{ Location } \\
\hline Urban (n=191) & $25.5(6.7)$ & $10.8(3.1)$ & $9.4(3.1)$ & $4.3(1.5)$ \\
\hline Coastal $(n=100)$ & $24.1(6.4)$ & $10.4(2.8)$ & $9.3(3.0)$ & $4.1(1.3)$ \\
\hline Rural (n=100) & $24.5(5.0)$ & $10.6(2.6)$ & $9.2(2.4)$ & $4.3(1.2)$ \\
\hline
\end{tabular}

Mean total fat intake was $24.9 \pm 6.2 \mathrm{~g} / 1000 \mathrm{kcal}$, of which $10.7 \pm 2.9 \mathrm{~g} / 1000 \mathrm{kcal}$ comprised of saturated fatty acids (SFA) (Table 7). Mean intake of monounsaturated fatty acids (MUFA) and polyunsaturated fatty acids (PUFA) were $9.3 \pm 2.9 \mathrm{~g} / 1000 \mathrm{kcal}$ and $4.3 \pm 1.4 \mathrm{~g} / 1000 \mathrm{kcal}$, respectively (Table 7). The only significant difference in fat consumption across all groups was the lower intake of SFA by the Chinese participants $(\mathrm{p}<0.05)$.

Overall, total fat, SFA and PUFA comprised $22.5 \%$, $9.6 \%$ and $3.8 \%$ respectively of total energy intake. These figures are within the recommended healthy eating guidelines (total fat should be less than $30 \%$ of total calories; saturated fat should be less than $10 \%$ of total calories). F\&S was not a significant contributor of PUFA, but cereal and cereal products and meat and meat products were (Table 8). Cereal and cereal products were also a significant contributor of SFA (Table 8). 
Table 8: The contribution (\%) of different food categories to the total fat, SFA, MUFA and PUFA consumed

\begin{tabular}{|l|l|l|l|l|l|l|l|}
\hline \multicolumn{2}{|l|}{ Food Categories } & $\begin{array}{l}\text { Cereal } \\
\text { and } \\
\text { cereal } \\
\text { products }\end{array}$ & $\begin{array}{l}\text { Meat } \\
\text { and meat } \\
\text { products }\end{array}$ & Eggs & $\begin{array}{l}\text { Legumes } \\
\text { and } \\
\text { pulses }\end{array}$ & $\begin{array}{l}\text { Fish } \\
\text { and } \\
\text { seafood }\end{array}$ & $\begin{array}{l}\text { Milk } \\
\text { and } \\
\text { dairy }\end{array}$ \\
\hline $\begin{array}{l}\text { Total } \\
\text { Fat }(\%)\end{array}$ & Mean & 29.7 & 12.7 & 11.7 & 8 & 5.1 & 4.9 \\
\cline { 2 - 8 } & \pm SD & 13.3 & 13.4 & 9.4 & 9.8 & 6 & 7.9 \\
\cline { 2 - 8 } & Median & 28.2 & 8.4 & 9.1 & 4.7 & 3.1 & 2.1 \\
\hline $\begin{array}{l}\text { SFA } \\
(\%)\end{array}$ & Mean & 28.1 & 9.5 & 8.4 & 3.6 & 4.4 & 6.9 \\
\cline { 2 - 8 } & \pm SD & 14.4 & 11.3 & 7.5 & 5.1 & 4.9 & 10.1 \\
\cline { 2 - 8 } & Median & 25.6 & 5.6 & 6.3 & 1.9 & 2.9 & 3.3 \\
\hline $\begin{array}{l}\text { MUFA } \\
(\%)\end{array}$ & Mean & 26.8 & 19.7 & 13.8 & 9.4 & 3.8 & 3.9 \\
\cline { 2 - 8 } & \pm SD & 13.2 & 17.6 & 10.7 & 12 & 5.4 & 6.6 \\
\cline { 2 - 8 } & Median & 25.3 & 14.6 & 11.1 & 5.2 & 1.9 & 1.6 \\
\hline \multirow{4}{*}{$\begin{array}{l}\text { PUFA } \\
(\%)\end{array}$} & Mean & 33.8 & 21.1 & 7.8 & 13.5 & 5.3 & 1.1 \\
\cline { 2 - 8 } & \pm SD & 13.7 & 17.6 & 6.6 & 13.6 & 6.9 & 2.1 \\
\cline { 2 - 8 } & Median & 32.8 & 16.8 & 3 & 9.8 & 3 & 0.4 \\
\hline
\end{tabular}

\section{DISCUSSIONS}

\section{Generalisability and segmentation of $F \& S$ consumption pattern}

The average amount of F\&S consumed by participants in this study ( $122 \mathrm{~g} /$ day) is comparable to the findings of another national study ( $147 \mathrm{~g} /$ day) conducted by Ahmad et al (2016). Their study extended from Selangor and the Klang Valley into the neighbouring state of Negeri Sembilan, which is less urbanised and therefore may explain the slightly higher estimates of daily F\&S consumption. Coastal and rural participants in this study consumed similar amounts (about $142 \mathrm{~g} /$ day), compared to just $101 \mathrm{~g} /$ day among the urban dwellers. Although Ahmad et al. (2016) managed to produce a list of the ten most frequently consumed marine F\&S from their surveys, the questionnaire was participant-administered and $40 \%$ of the participants did not name the F\&S consumed. Generally, both studies reported that Indian mackerel is consumed in the largest amounts by all participants, regardless of location, and anchovies and Indian mackerel are the two most popular species by frequency of consumption. Other F\&S on the lists of most consumed species by weight and by frequency are fairly similar in both studies. Both studies also showed that Malaysians favour marine over freshwater F\&S. Ahmad et al (2016) noted that prawns (without delineation of types) are highly popular while this study pinpointed Vannamei prawn as the most popular variant.

Coastal fisheries supply around $75 \%$ of the F\&S available in Malaysia, the remainder coming from aquaculture or from imported species (DoFM, 2009-2014). This is in line with our finding that marine captured F\&S accounts for more than $75 \%$ of the total F\&S consumed. It is evident that Malaysians favour wild $F \& S$ over farmed
F\&S. As predicted, this affinity for wild F\&S is more prevalent in the coastal region, reflecting the availability of wild sea F\&S and, perhaps, the long history of sea fishing, which has provided a lifeline for many generations. Surplus of sea-harvest are traditionally made into "keropok lekor", which explains why this snack is more heavily consumed in the coastal areas. Aquaculture contributes to the remaining $25 \%$ of the country's F\&S production. The major production of brackish species is Vannamei prawn and high value marine fish, e.g. grouper (DoFM, 2009-2014). Vanammei prawn is a popular farmed species across all geographical locations, mainly because it is the affordable option (RM $35 / \mathrm{kg}^{*}$ ) of otherwise very expensive wild-captured sea prawns (RM 67/kg*). Grouper is generally raised as an export commodity, and hence was not popular amongst the participants in this study.

Rural dwellers are more receptive of farmed freshwater $\mathrm{F} \& \mathrm{~S}$ as inland fish farms are scattered throughout their locality. Of the commercially cultured freshwater species in Malaysia, catfish accounts for $45.2 \%$ of the total freshwater aquaculture production, followed by red tilapia (27.0\%) and carp (10.1\%) (DoFM, 2009-2014) - all of which were reported to be more widely consumed by rural dwellers in this study. Among those who consume farmed F\&S, the Chinese consumed a significantly larger proportion, mainly contributed by tilapia. This species of fish features in many popular dishes both at home and in restaurants. The urban participants on the other hand appear to like more diverse and "exotic" species. They report the consumption of a wider range of F\&S, e.g. imported fish (salmon) and bivalves (clams and cockles) that are less common among their rural and coastal counterparts. This is unsurprising as trends towards the concept of "experience new and different things" become widespread in the increasing globalisation of urban economies (Camillo, 2015).

Small pelagic fish from lower trophic levels constitute most of the commonly consumed wild captured F\&S. Dried young anchovies ranging from 2 to $5 \mathrm{~cm}$ in length, known in Malaysia as "ikan bilis", are ubiquitous in Malaysian kitchens. "Ikan bilis" is one of the main condiments for nasi lemak, one of Malaysia's most popular everyday foods. Anchovies are also consumed deep-fried as snacks, stir-fried with vegetables, and made into soup. In addition to the economic reasons for selecting small sized fish, it is worth noting that the eating habit and dining style of Malaysians, especially the Malay ethnic majority group, is inclined towards servings of small whole fish such as Indian mackerel (Othman, n.d.), which typically weights from 8 to 10 fishes per kilogram (100-120g per fish). One plausible explanation is that these fish are appropriately sized such that one fish can be served per person. In fact, a dated urban survey revealed that the Indian mackerel was ranked the most popular fish due to its low cost and suitable size (Osman et al., 2001). The big or high value fish are only eaten during festive seasons (Othman, n.d.).

\section{$F \& S$ and protein intake}


The Malaysian food-based dietary guidelines (Ministry of Health Malaysia, 2010) recommend one serving of any type of F\&S per day. There is no quantification of serving size, but this guideline assumes that one serving will provide $14 \mathrm{~g}$ of protein for a $2000 \mathrm{kcal}$ diet (Ministry of Health Malaysia, 2010). On average, F\&S contain approximately $20 \mathrm{~g}$ of protein per $100 \mathrm{~g}$ of edible portion of raw weight (Ministry of Health Malaysia, 2010). In Malaysia, fish are normally served whole, which means there is a large proportion of inedible material in one serving. After accounting for an average of about $50 \%$ of edible portion, the recommended serving of $F \& S$ (to provide a protein intake of $14 \mathrm{~g}$ ) is equivalent to $140 \mathrm{~g}$ of unprepared $\mathrm{F} \& S$ (i.e. uncooked, bone-in) per day. Both the coastal and rural dwellers reported an average intake of around $142 \mathrm{~g}$ of unprepared F\&S per day, which meets the Malaysian dietary guideline. However, the urban participants reported lower average daily intakes of about $100 \mathrm{~g}$ of unprepared F\&S, which is approximately $30 \%$ short of the recommended amount.

In terms of total protein intake, the lower than recommended intake of $F \& S$ by the urban participants may not be a cause for concern since they consumed protein from other sources. While it was not the main aim of this study, it was apparent from the FFQ that all participants consumed on average one-fold more meat and poultry $(\approx 27 \mathrm{~g}$ of protein) than the recommended daily serving $(\approx 14 \mathrm{~g}$ of protein) (Ministry of Health Malaysia, 2010). Data from this study indicate a plant to animal ratio in the order of $3: 4$, which is far from the proposed optimal ratio of at least 4:1 (Burlingame, 2015). These findings echo those of MANS 2014, which highlighted an over-consumption of meat and poultry and reported that around $82 \%$ of Malaysian adults failed to meet the recommended intake for plant protein. With rising incomes and urbanisation, Malaysians are consuming more animal protein than before (Drewnowski \& Popkin, 1997; Hawkes et al., 2017). This is especially true among the Chinese and urban participants in this study who consumed significantly more meat than their counterparts; as of 2016, ethnic Chinese had the highest monthly household income in Malaysia. There are also strong crosscultural associations between meat and masculinity (Rothgerber, 2013; Love \& Sulikowski, 2018), which could explain the significantly higher consumption of meat by males in this study.

The Malaysian recommended intakes for F\&S are notably higher than in other parts of the world. For instance, the recommendations of the British Dietetic Association (2016) and the American Heart Association (2016) are for at least two portions of fish per week, including one of oily fish. The Health Promotion Board of Singapore (Ministry of Health Singapore, 2014), Malaysia's closest neighbour who shares a joint heritage and similar dietary habits, also calls for at least two servings of fish per week. While there is no official justification from the Malaysian $\mathrm{MoH}$ for this recommendation, one plausible explanation may be linked to the differences in fatty acid composition of tropical versus temperate water fish. Fish from temperate regions tend to have a higher concentration of the beneficial long chain polyunsaturated fatty acids than those from tropical waters (Taşbozan \& Gökçe, 2017). This theory, however, does not explain the difference in recommendations between Malaysia and Singapore.

\section{$F \& S$ and fats intake}

The patterns of fat consumption by participants in this study (total fat, SFA and PUFA at $22.5 \%, 9.6 \%$ and $3.8 \%$ of total energy intake) are within the recommended dietary guidelines, although the proportion of SFA is bordering on the maximum recommended levels (10\% of the energy intake) and the PUFA is on the low side of the recommended range. WHO suggested that total fat should not exceed $30 \%$ of total EI (WHO, 2008) while RNI Malaysia suggested keeping SFA below $10 \%$ of total EI (Institute of Public Health, 2014). As for PUFA, WHO suggested that a range of 3.6-11.2\% of total calories should be consume (WHO, 2008). There is convincing evidence that replacing SFA with PUFA decreases LDL cholesterol concentration and the total/HDL cholesterol ratio and thus the risk of $\mathrm{CHD}$ (WHO, 2008). The minimum intake levels of PUFA to prevent deficiency symptoms are estimated at $2.5-3.5 \%$ but the minimum recommended level to be effective for decreasing the risk of CHD events is $6 \%$ (WHO, 2008).

Essential fatty acids (EFA) are PUFAs that cannot be synthesised by the body. The omega-6 linoleic acid (LA) and the omega-3 a-linolenic acid (ALA) comprise the two classes of EFA. These are parent compounds to longer chain derivatives, e.g. eicosapentaenoic acid (EPA) and docosahexaenoic acid (DHA), in the body. Omega-3s play important roles as integral parts of cell membranes (Surette, 2008). Omega-3s, along with omega-6s, are used to form eicosanoids. Eicosanoids are signalling molecules with wide-ranging functions in the cardiovascular, pulmonary, immune, and endocrine systems (Jones \& Papamandjaris, 2012; Jones \& Rideout, 2014). Despite the importance of essential fatty acids in the diet, this study could only estimate the amount of total PUFA, but not its EFA composition, due to a lack of data in the food composition databases for local F\&S. The Malaysian Food Composition Database has no information of fatty acid composition and hence references to the Singaporean databases had to be made. However, the Singaporean database only provides total PUFA values for all food items involved.

Studies have shown that over the last 150 years, dietary intakes of omega- 6 have increased along with decreased intakes of omega-3. This has been in parallel with an increase in heart disease (Simopoulos, 2001), leading to the development of an "ideal" ratio of omega- 6 to omega- 3 fatty acids for cardiovascular health (Simopoulos, 2008). This concept is still in development and until now there is no consensus on an optimal ratio. However, it is acknowledged that raising EPA and DHA blood levels is far more important than lowering the levels of omega-6 (EFSA Panel, 2010). Due to low efficiency of conversion of ALA to EPA and DHA, it is recommended to obtain them from dietary sources. It is well known that fish lipids are the main sources of EFA, especially EPA and DHA (Osman et al., 
2001). Despite high consumption of fish, the overall PUFA intake $(3.8 \%)$ of participants in this study is at the lower extremity of WHO recommendations. This is not surprising as the popular fish in this study are not good sources of PUFA. Nonetheless, a handful of studies have found that a few less popular local fish species are potential sources of EFA that have the potential to meet the recommended nutrient intake (Osman et al., 2001; Osman et al., 2007; Ng, 2006; Wan Rosli et al., 2012; Muhamad and Mohamad, 2012; Mohd and Abdul Manan, 2012; Abd Aziz et al., 2013). Endinkeau and Tan (1993) found that the EFA levels in a local freshwater eel, the "belut sawah", are comparable to those of salmon. Recommendations to improve nutritional status through increased consumption of selected fish must be considered alongside concerns for the sustainability and potential depletion of fish stocks.

It appears that cereal and cereal products and meat and meat products are the main contributors to PUFA in the diet of participants in this study, with cereal and cereal products also being the main contributor of SFA. The contribution of PUFA and SFA from cereal products is attributed to a high intake of processed foods that use palm oil in their manufacture. This is mainly due to the type of vegetable oil used in the processing of cereal products. In Malaysia, palm oil is the most widely used vegetable oil and has roughly equal amount of SFA (45.3\%) and unsaturated fatty acids (41.6\% MUFA and $8.3 \%$ PUFA) (Ministry of Health Singapore, 2011). Except for plain white boiled rice and oats, all other cereal items listed in the FFQ (e.g. fried rice, yellow noodle, rice noodle, instant noodle, bread and "roti canai") contain various amounts of palm oil. Chicken, being the second most popular source of animal protein after F\&S, has a lower proportion of SFA and a higher proportion of PUFA than other meat (Barroeta, 2007). The presence of higher levels of PUFA in chicken may be due to the addition of oilseed crops in poultry diets. In monogastric animals, especially in chickens, it is well established that the fatty acids profile of feed directly affects the fatty acids composition of fat depots (Barroeta, 2007).

\section{Potential implications of current $F \& S$ consumption habit}

To meet the high demand of F\&S from local water, the number of fishing licenses issued in Malaysia increased by $15 \%$ from 2009 to 2014 (DoFM, 2009-2014). However, according to the DoFM records, while the fishing effort increased significantly, the number of marine F\&S landed remained constant, signifying a depletion of fish stock in the ocean (DoFM, 2009-2014). Since the local catch fails to satisfy demand, Malaysia needs to import F\&S to ensure a sufficient supply. As of 2014, Malaysia was a net importer for a number of popular F\&S mentioned in this study, i.e. mackerels, sardines, scads, rays and pomfrets. The deficit was highest for mackerels (DoFM, 2009-2014). Aquaculture has been actively promoted in Malaysia as a means to increase self-sufficiency. There is the potential for farmed species to meet the extra demand for F\&S, and also for the farmed species to close the EFA gap. The lipid composition of farmed species is highly dependent on the nutritional quality of feed (Sprague et al., 2016) and thus can be manipulated by F\&S farmers and producers of aquaculture feed sustainably using novel ingredient such as microalgae (Adarme-Vega et al., 2012; Stoneham et al., 2018). However, data collected in this study suggests that, although consumers like to eat $\mathrm{F} \& \mathrm{~S}$, their preference is very much for wild caught over farmed species.

Malaysian's preference for wild caught over farmed species has not been studied yet. However, it is likely to be due to the negative perceptions of farmed F\&S as being inferior in quality. For example, intensive production raises concerns over the inferior quality of farmed fish in terms of bioaccumulation of toxins and metals (Hites et al., 2004; Cretì et al., 2010) and compromised fatty acid profile (Karapanagiotidis et al., 2006; Usydus et al., 2011) compared to the wild equivalent. Farmed prawns from Malaysia were banned by the US FDA due to the presence of prohibited antibiotics (FDA, 2016). This was widely reported in Malaysia, which could have resulted in general distrust in quality and safety of farmed F\&S. One could question how effective aquaculture will be at meeting the total demand for $F \& S$ in Malaysia when negative perceptions may prevent this from being a viable option. In the absence of effective governance and sustainability awareness, aquaculture can do more harm than good. Pollution loading and the clearing of mangroves for the construction of prawn farms are reported to cause deterioration in the state of coastal natural resources and the environment (Ashton, 2008; Berlanga-Robles et al., 2011). While aquaculture does have the potential to fill the gap, it must be regulated to ensure high quality, nutritious sustainable products.

\section{Limitations of the study}

While the inherent weakness of FFQ in terms of absolute accuracy was expected, the FFQ result of this study was deemed as a close estimate. The actual mean energy intake of female and male participants was underestimated by only 9.4\% and $4.3 \%$ respectively, after accounting for misreporters. The prevalence of mis-reporters in this study was also similar to, if not lower than, those reported in the literature. Poslusna et al. (2009) reported in their systematic review that the mean prevalence of under-reporting in the literature ranged from 11.9 to $67 \%$, with a median at approximately $30 \%$, while over-reporting ranged from 3.5 to $7 \%$ (median 4.1 ). The corresponding number of under and over reporters in in this study are about $30 \%$ and $1.8 \%$ of the sample population respectively.

This study was carried out in the greater Klang Valley and Selangor. Although it included data from rural, urban, and coastal populations within the region, it is acknowledged that this may not be representative of the entire Malaysian population. While we acknowledge that we should extrapolate the findings to other states with caution, we consider that the trends in eating behaviour are applicable to the wider population. If anything, the results of this study may give a preview of how trends could develop in other states of Peninsular Malaysia as they become more 
economically developed and diets transition from largely traditional to those influenced by the West.

\section{CONCLUSIONS}

It is apparent that, at the current time, F\&S, particularly those of the wild origins, is the most popular source of dietary protein in most sectors of the Malaysian adult population. The fact that the Malaysian fish demand has to be fulfilled by supplies beyond its domestic waters implores further investigation. It is imperative that we revisit the dietary guideline and evaluate how our food system can keep pace with increasing demands. For most wild capture fisheries, 'sustainability' is formally assessed through stock assessments (FAO, 2018). The list of commonly consumed F\&S generated from this study would serve as the necessary baseline information for such an assessment. The findings on $\mathrm{F} \& S$ consumption patterns can guide future research to explore the potential for (and challenges involved in) efforts to enhance farm fisheries' contribution to future healthy and sustainable diets. One should understand that F\&S is only one component of a varied diet. The general trend towards over-consumption of animal protein other than F\&S found in this study, would also impact on human and environment health, and hence deserves further attention.

\section{REFERENCES}

Abd Aziz, N., Azlan, A., Ismail, A., Mohd Alinafiah, S. and Razman, M.R., 2013. Quantitative determination of fatty acids in marine fish and shellfish from warm water of Straits of Malacca for nutraceutical purposes. BioMed Research International.

Adarme-Vega, T.C., Lim, D.K., Timmins, M., Vernen, F., Li, Y. and Schenk, P.M., 2012. Microalgal biofactories: a promising approach towards sustainable omega-3 fatty acid production. Microbial Cell Factories, 11(1), pp.110 .

AHA, 2016. Fish and Omega-3 Fatty Acids. Retrieved from: http://www.heart.org/HEARTORG/HealthyLiving/Heal thyEating/HealthyDietGoals/Fish-and-Omega-3-FattyAcids_UCM_303248_Article.jsp\#.WdGPJfOGPIU

Ahmad, N.I., Wan Mahiyuddin, W.R., Tengku Mohamad, T.R., Ling, C.Y., Daud, S.F., Hussein, N.C., Abdullah, N.A., Shaharudin, R. and Sulaiman, L.H., 2016. Fish consumption pattern among adults of different ethnics in Peninsular Malaysia. Food \& Nutrition Research, 60(1), p.32697.

Ashton, E.C., 2008. The impact of shrimp farming on mangrove ecosystems. CAB Reviews: Perspectives in Agriculture, Veterinary Science, Nutrition and Natural Resources, 3(003).
Barroeta, A.C., 2007. Nutritive value of poultry meat: relationship between vitamin $\mathrm{E}$ and PUFA. World's poultry science journal, 63(2), pp.277-284.

BDA, 2016. Food Fact Sheets: Healthy Eating. Retrieved from: https://www.bda.uk.com/foodfacts/HealthyEating.pdf

Berlanga-Robles, C.A., Ruiz-Luna, A. and HernándezGuzmán, R., 2011. Impact of shrimp farming on mangrove forest and other coastal wetlands: the case of Mexico. Aquaculture and the Environment-A Shared Destiny. IntechOpen, pp.17-30.

Bingham, S.A., 1994. The use of 24-h urine samples and energy expenditure to validate dietary assessments. The American journal of clinical nutrition, 59(1), pp.227S$231 \mathrm{~S}$.

Burlingame, B., 2015. Plant/animal protein ratio. Assessing Sustainable Diets Within the Sustainability of Food Systems, p.95.

Camillo, A.A. ed., 2015. Handbook of Research on Global Hospitality and Tourism Management. IGI global.

Cretì, P., Trinchella, F. and Scudiero, R., 2010. Heavy metal bioaccumulation and metallothionein content in tissues of the sea bream Sparus aurata from three different fish farming systems. Environmental Monitoring and Assessment, 165(1), pp.321-329.

DoFM. 2009 - 2014. National annual fisheries statistics were obtained from official spreadsheets and reports uploaded by the Department of Fisheries, Malaysia on its open data portal:http://www.dof.gov.my/index.php/pages/view/82

DoSM. 2016. National demographics and socio-economic data were obtained from official spreadsheets and reports uploaded by the Department of Statistics, Malaysia on its open data portal: https://www.dosm.gov.my/v1/index.php?r=column3/ac cordionandmenu_id=aHhRYUpWS3B4VXIYaVBOeU F0WFpWUT09

Drewnowski, A. and Popkin, B.M., 1997. The nutrition transition: new trends in the global diet. Nutrition Reviews, 55(2), pp.31-43.

Drewnowski, A., 2005. Concept of a nutritious food: toward a nutrient density score. The American Journal of Clinical Nutrition, 82(4), pp.721-732.

EFSA Panel (2010) Dietetic Products, Nutrition, and Allergies (NDA). Scientific Opinion on Dietary 
Reference Values for fats, including saturated fatty acids, polyunsaturated fatty acids, monounsaturated fatty acids, trans fatty acids, and cholesterol. EFSA Journal $8(3): 1461$.

Endinkeau, K. and Tan, K.K., 1993. Profile of fatty acid contents in Malaysian freshwater fish. Pertanika Journal of Tropical Agricultural Science (Malaysia).

FAO and WHO, 2019. Sustainable healthy diets - Guiding principles. Rome.

FAO, 2001. FAO Food Balance Sheets: A Handbook. Food and Agriculture Organization of the United Unions, Rome.

FAO, 2005. Report and documentation of the International Workshop on Factors Contributing to Unsustainability and Over-exploitation in Fisheries. Siem Reap, Cambodia, 13-16 September 2004. FAO Fisheries Report, 782 .

FAO, 2018. The State of World Fisheries and Aquaculture 2018-Meeting the sustainable development goals. FAO.

FAO, 2020. The State of World Fisheries and Aquaculture 2020. Sustainability in Action. Food and Agriculture Organization of the United Nations.

FDA, 2016. Constituent Update: FDA Issues Import Alert on Imported Shrimp and Prawns from Peninsular Malaysia. Retrieved from: https://www.fda.gov/Food/NewsEvents/ConstituentUpd ates/ucm496475.htm

Ferreira, M.G., Silva, N.F.D., Schmidt, F.D., Silva, R.M.V.G.D., Sichieri, R., Guimarães, L.V. and Pereira, R.A., 2010. Development of a Food Frequency Questionnaire for adults in a population-based sample in Cuiabá, Mid-Western Region of Brazil. Revista Brasileira de Epidemiologia, 13(3), pp.413-424.

Gay, L.R., 1996. Educational Research: Competencies for Analysis and Application. Beverly Hill, CA: Sage Publications.

Gibson, R.S., 2005. Principles of nutritional assessment. USA: Oxford University Press.

Goldberg, G.R., Black, A.E., Jebb, S.A., Cole, T.J., Murgatroyd, P.R., Coward, W.A. and Prentice, A.M., 1991. Critical evaluation of energy intake data using fundamental principles of energy physiology: 1 . Derivation of cut-off limits to identify under-recording. European Journal of Clinical Nutrition, 45(12), pp.569581.
Hawkes, C., Harris, J. and Gillespie, S., 2017. Changing diets: Urbanization and the nutrition transition. IFPRI book chapters, pp.34-41.

Hites, R.A., Foran, J.A., Carpenter, D.O., Hamilton, M.C., Knuth, B.A. and Schwager, S.J., 2004. Global assessment of organic contaminants in farmed salmon. Science, 303(5655), pp.226-229.

Institute of Public Health, 2008a. Malaysian Adult Nutrition Survey (MANS) 2003 Vol. 5: Dietary Intake of Adults Aged 18 to 59 Years. Downloaded from: http://iku.moh.gov.my/images/IKU/Document/REPOR T/MANS2003/Volume5-DietaryIntakeOfAdults.pdf

Institute of Public Health, 2008b. Malaysian Adult Nutrition Survey (MANS) 2003 Vol. 7: Habitual Food Intake of Adults Aged 18 to 59 Years. Downloaded from: http://iku.moh.gov.my/images/IKU/Document/REPOR T/MANS2003/Volume7-HabitualFoodIntake.pdf

Institute of Public Health, 2014. Malaysian Adult Nutrition Survey (MANS) 2014 Vol. III: Food Consumption Statistics of Malaysia. Downloaded from: http://iku.moh.gov.my/images/IKU/Document/REPOR T/NHMS2014-MANS-VOLUME-3-

FoodConsumptionStatisticsofMalaysia.pdf

Ismail, M.N., Ng, K.K., Chee, S.S., Roslee, R. and Zawiah, H., 1998. Predictive equations for the estimation of basal metabolic rate in Malaysian adults. Malaysian Journal of Nutrition, 4(1 \& 2), pp.81-90.

Jones, P.J., Papamandjaris, A.A., 2012. Lipids: cellular metabolism. Present knowledge in nutrition. Present Knowledge in Nutrition. 10th ed. Washington, DC: Wiley-Blackwell.

Jones, P.J., Rideout, T, 2014. Lipids, sterols, and their metabolites. Modern Nutrition in Health and Disease. 11th ed. Baltimore, MD: Lippincott Williams \& Wilkins.

Karapanagiotidis, I.T., Bell, M.V., Little, D.C., Yakupitiyage, A. and Rakshit, S.K., 2006. Polyunsaturated fatty acid content of wild and farmed tilapias in Thailand: effect of aquaculture practices and implications for human nutrition. Journal of Agricultural and Food Chemistry, 54(12), pp.4304-4310.

Kearney, J., 2010. Food consumption trends and drivers. Philosophical transactions of the royal society B: Biological Sciences, 365(1554), pp.2793-2807.

Love, H.J. and Sulikowski, D., 2018. Of meat and men: Sex differences in implicit and explicit attitudes toward meat. Frontiers in Psychology, 9, p.559. 
Loy, S.L., Marhazlina, M., Azwany, Y. and Jan, J.M., 2011. Development, validity and reproducibility of a food frequency questionnaire in pregnancy for the Universiti Sains Malaysia birth cohort study. Malaysian Journal of Nutrition, 17(1).

Ministry of Health Singapore, 2011. Singapore Food Composition Database: Energy and Nutrient Composition of Food. Available from: focos.hpb.gov.sg/eservices/ENCF/

Ministry of Health Singapore, 2014. My Healthy Plate. Retrieved from: https://www.healthhub.sg/programmes/55/my-healthyplate

Ministry of Health, 2010. Malaysian Dietary Guidelines. Nutrition Division, Ministry of Health Malaysia, Putrajaya.

Muhamad, N.A. and Mohamad, J., 2012. Fatty acids composition of selected Malaysian fishes. Sains Malaysiana, 41(1), pp.81-94.

Ng, T.K.W., 2006. Omega-3 fatty acids: Potential sources in the Malaysian diet with the goal towards achieving recommended nutrient intakes. Malaysian Journal of Nutrition, 12(2), pp.181-188.

Osman, F., Jaswir, I., Khaza'ai, H. and Hashim, R., 2007. Fatty acid profiles of fin fish in Langkawi Island, Malaysia. Journal of Oleo Science, 56(3), pp.107-113.

Osman, H., Suriah, A.R. and Law, E.C., 2001. Fatty acid composition and cholesterol content of selected marine fish in Malaysian waters. Food Chemistry, 73(1), pp.5560 .

Othman, M.F., (n.d.). Challenges ahead in meeting aquaculture production in Malaysia under the third National Agricultural Policy, NAP3 (1998-2010).

Poslusna, K., Ruprich, J., de Vries, J.H., Jakubikova, M. and van't Veer, P., 2009. Misreporting of energy and micronutrient intake estimated by food records and 24 hour recalls, control and adjustment methods in practice. British Journal of Nutrition, 101(S2), pp.S73-S85.

Puwastien, P., Burlingame, B., Raroengwichit, M., et al, (2000). ASEAN food composition tables. Institute of Nutrition, Mahidol University (INMU), ASEANFOODS Coordinator and INFOODS Regional Database Centre, Bangkok, Thailand.

Rosli, W.W., Rohana, A.J., Gan, S.H., Fadzlina, H.N., Rosliza, H., Helmy, H., Nazri, S.M., Ismail, I.M., Bahri,
I.S., Mohamad, W.W. and Imran, M.K., 2012. Fat content and EPA and DHA levels of selected marine, freshwater fish and shellfish species from the east coast of Peninsular Malaysia. International Food Research Journal, 19(3), p.815.

Rothgerber, H., 2013. Real men don't eat (vegetable) quiche: Masculinity and the justification of meat consumption. Psychology of Men \& Masculinity, 14(4), p.363.

Simopoulos, A.P., 2001. Evolutionary aspects of diet, essential fatty acids and cardiovascular disease. European Heart Journal Supplements, 3(suppl_D), pp.D8-D21.

Simopoulos, A.P., 2008. The importance of the omega6/omega-3 fatty acid ratio in cardiovascular disease and other chronic diseases. Experimental Biology and Medicine, 233(6), pp.674-688.

Sprague, M., Dick, J.R. and Tocher, D.R., 2016. Impact of sustainable feeds on omega-3 long-chain fatty acid levels in farmed Atlantic salmon, 2006-2015. Scientific Reports, 6(1), pp.1-9.

Stoneham, T.R., Kuhn, D.D., Taylor, D.P., Neilson, A.P., Smith, S.A., Gatlin, D.M., Chu, H.S.S. and O'Keefe, S.F., 2018. Production of omega-3 enriched tilapia through the dietary use of algae meal or fish oil: Improved nutrient value of fillet and offal. PloS One, 13(4), p.e0194241.

Surette, M.E., 2008. The science behind dietary omega-3 fatty acids. CMAJ, 178(2), pp.177-180.

Suzana, S., Rafidah, G., Noor Aini, M.Y., Nik Shanita, S., Zahara, A.M. and Shahrul Azman, M.N., 2009. Atlas Makanan: Saiz pertukaran dan Porsi. Universiti Kebangsaan Malaysia.

Taşbozan, O. and Gökçe, M.A., 2017. Fatty acids in fish. Fatty Acids, 1, pp.143-159.

Tee, E.S., Noor, M.I., Azudin, M.N., et al, 1997. Nutrient compositions of Malaysian foods 4th edn. Institute for Medical Research Malaysia, Kuala Lumpur.

Tooze, J.A., Krebs-Smith, S.M., Troiano, R.P. and Subar, A.F., 2012. The accuracy of the Goldberg method for classifying misreporters of energy intake on a food frequency questionnaire and 24-h recalls: comparison with doubly labeled water. European Journal of Clinical Nutrition, 66(5), pp.569-576. 
Usydus, Z., Szlinder-Richert, J., Adamczyk, M. and Szatkowska, U., 2011. Marine and farmed fish in the Polish market: Comparison of the nutritional value. Food Chemistry, 126(1), pp.78-84.

WHO, 2008. Interim summary of conclusions and dietary recommendations on total fat \& fatty acids. From the Joint FAO/WHO Expert Consultation on Fats and Fatty Acids in Human Nutrition, 10-14 November, 2008, WHO, Geneva. 


\section{Appendix I - Latin Names of Commonly Consumed}

\section{Fish in Malaysia}

$\begin{array}{ll}\text { No } & \text { English Name } \\ 1 & \text { Anchovy } \\ 2 & \text { Barramundi } \\ 3 & \text { Big Head Carp } \\ 4 & \text { Black Pomfret } \\ 5 & \text { Blood Cockle } \\ 6 & \text { Catfish } \\ 7 & \text { Fourfinger Threadfin } \\ 8 & \text { Hardtail Scad } \\ 9 & \text { Indian Mackerel } \\ 10 & \text { Lala Clam } \\ 11 & \text { Red Snapper } \\ 12 & \text { Red Tilapia } \\ 13 & \text { Round Scad } \\ 14 & \text { Salmon } \\ 15 & \text { Sardine } \\ 16 & \text { Small Tuna } \\ 17 & \text { Sole Fish } \\ 18 & \text { Spanish Mackerel } \\ 19 & \text { Stingray } \\ 20 & \text { Threadfin Bream } \\ 21 & \text { Tiger Prawn } \\ 22 & \text { Vannamei Prawn } \\ 23 & \text { White Pomfret } \\ & \end{array}$

Latin Name
Stolephorus spp.
Lates calcarifer
Hypophthalmichthys nobilis
Parastromateus niger
Anadara granosa
Clarias batrachus
Eleutheronema tetradactylum
Megalaspis cordyla
Rastrelliger kanagurta
Orbicularia orbiculata
Lutjanus campechanus
Oreochromis spp.
Selaroides leptolepis
Salmo salar
Sardinella spp
Euthynnus affinis
Pseudorhombus Arsius
Scomberomorus commerson
Dasyatidae spp.
Nemipterus bathybius
Penaeus monodon
Penaeus vannamei
Pampus argenteus

